УДК 378.4

АКТАМОВ Иннокентий Галималаевич - кандидат педагогических наук, заведующий лабораторией «Центр переводов с восточных языков» Института монголоведения, буддологии, тибетологии СО РАН (670047, Россия, Республика Бурятия, г. Улан-Удэ, ул. Сахьяновой, 6; aktaтоv13@ gmail.com)

БАНЗАРОВА Айдана Ховар-Белековна - студентка Восточного института Бурятского государственного университета им. Доржи Банзарова (670000, Россия, Республика Бурятия, г. Улан-Удэ, ул. Смолина, 24a, aydana.dongak@yandex.ru)

\title{
ОСОБЕННОСТИ ПРОЦЕССА ИНТЕГРАЦИИ УНИВЕРСИТЕТОВ ГОНКОНГА И КНР В СОВРЕМЕННЫХ УСЛОВИЯХ
}

\begin{abstract}
Аннотация. В рамках данной статьи предпринята попытка выявить основные характерные черты процесса интеграции вузов Гонконга и КНР. Условно можно выделить два основных этапа интеграции: начиная с конца 1980-х гг. до 1997 г. и после возвращения Гонконга (Сянгана, 香港) в состав КНР. Определены основные механизмы интеграции вузов, выявлены мотивы поступления абитуриентов Гонконга в вузы материкового Китая. Несмотря на неоднозначное отношение жителей Гонконга к политике центрального правительства, процесс интеграции в образовании носит двусторонний характер.

Ключевые слова: КНР, Гонконг (Сянган), высшее образование, интеграция, образовательная политика
\end{abstract}

\section{Введение}

Изучение различных аспектов развития современного китайского общества и государства вызывает большой интерес в среде ученых. Политическое и экономическое положение, которое занимает КНР в глобальном мироустройстве в XXI в., весьма резонно заставляет пристальнее присматриваться к процессам и отдельным событиям, происходящим в Поднебесной. Одним из наиболее важных событий конца XX в. для Китая является возвращение Сянгана (Гонконга) и Аомэня (Макао) под юрисдикцию КНР. По результатам Второй опиумной войны в 1898 г. было подписано соглашение, согласно которому территория Сянгана передавалась Великобритании в аренду на 99 лет. В соответствии с соглашением между Китаем и Великобританией с 1 июля 1997 г. Гонконг стал особым административным районом КНP ${ }^{1}$. Китай гарантировал автономное экономическое развитие Сянгана на протяжении ближайших 50 лет в соответствии с формулой «одна страна - две системы» (так же, как впоследствии и для Макао). Вопросы внешней политики и обороны определялись Пекином. С конца XX в. Гонконг демонстрирует стремительный экономический рост. После возвращения в состав КНР Сянган стал важнейшим торгово-транспортным узлом Южного Китая. Стратегия развития Гонконга основывается на принципах свободного рынка, минимальных ограничениях в торговле, делается ставка на высокотехнологичное и инновационное производство, а также на гибкую систему налогообложения. Продолжая британскую экономическую политику, Гонконг унаследовал и британскую ориентацию в области образования.

Современная система образования Гонконга является одной из самых кон-

1 Joint Declaration of the Government of the United Kingdom of Great Britain and Northern Ireland and the Government of the People's Republic of China on the Question of Hong Kong. Доступ: https://www.cmab.gov.hk/en/issues/jd2.htm (проверено 01.04.2021). 
курентоспособных. В обновленном рейтинге университетов мира $Q S$ World University Rankings Гонконгский университет занимает 22-е место, Гонконгский университет науки и технологий - 27 -е место, Китайский университет Гонконга - на 43-й позиции, Городской университет Гонконга на - 48-й позиции. Таким образом, четыре вуза Гонконга входят в топ-50 вузов мира. Для сравнения, приведем рейтинг лучших вузов континентального Китая: университет Цинхуа (清华大学) - на 15-й строчке, Пекинский университет (北京大学) - на 23-й, Фуданьский университет (复旦大学) - на 34-й, университет Цзяотун (交通大学) Шанхая - на 47-й позиции ${ }^{1}$.

Согласно данным другого рейтинга - The Times Higher Education World University Rankings 2021, вузы материкового Китая расположены несколько иначе. Так, университет Цинхуа - на 20-м месте, Пекинский университет - на 23 -й позиции. Гонконгский университет в данном рейтинге занял 39 -е место 2 . Остальные вузы КНР и Гонконга в топ-50 не вошли. Такие показатели стали возможны для вузов КНР по результатам реализации проектов «211» и «985». Указанные проекты были нацелены на обновление инфраструктуры университетов, создание новых исследовательских лабораторий, обеспечение условий для развития научно-педагогических кадров, в т.ч. с приглашением ведущих зарубежных специалистов для передачи передового опыта. Кроме того, в качестве основных механизмов модернизации образования КНР выступают Государственная программа среднесрочной и долгосрочной реформы и развития образования на 2010-2020 гг. [Гурулева 2020: 87] и План ускорения модернизации образования (2018-2022 гг. $)^{3}$. В настоящее время базовым стратегическим документом является Модернизация образования КНР до 2035 г. 4

Таким образом, учитывая внимание руководства КНР к системе образования и положению вузов в международных рейтингах, можно говорить, что КНР придает стратегическое значение развитию системы высшего образования. Более того, образование начинает рассматриваться как особый инструмент внешней политики Китая. Вузы Сянгана на современном этапе выступают неким символом и инструментом интеграции материкового Китая в международные образовательные процессы. Например, на сайте университета Гонконга в разделе «Вводная информация» говорится, что «первоначальная миссия Гонконгского университета заключалась в том, чтобы стать англоязычным университетом Китая. Мы вступаем во второе столетие, эта миссия по-прежнему актуальна, но контекст радикально изменился, все еще меняется и останется динамичным и непредсказуемым в обозримом будущем» 5 . Процесс интеграции континентального Китая и Сянгана был запущен в 1978 г. - с начала политики реформ и открытости. Это коснулось в т.ч. и университетской системы.

1 QS World University Rankings. URL: https://www.topuniversities.com/university-rankings/ world-university-rankings/2021 (accessed 01.04.2021).

2 The Times Higher Education World University Rankings 2021. URL: https://www. timeshighereducation.com/world-university-rankings/2021/world-ranking\#!/page/1/length/25/ sort_by/rank/sort_order/asc/cols/stats (accessed 01.04.2021).

$3^{-}$加快推进教育现代化实施方案 (2018-2022年)[План ускорения модернизации образования 2018-2022 гг.]. Доступ: http://djw.swsm.edu.cn/info/1041/1341.htm (проверено 04.04.2021).

4 中共中央、国务院印发《中国教育现代化2035》[Программа модернизации образования КНР 2035]. Доступ: http://www.gov.cn/zhengce/2019-02/23/content_5367987.htm (проверено 04.04.2021).

5 Официальный сайт университета Гонконга. Доступ: https://www.sppoweb.hku.hk/ vision2016-2025/introduction.html (проверено 04.04.2021). 


\section{Начальный этап интеграции}

Интеграция Гонконга и КНР, несмотря на все нюансы, исторически представлялась процессом объективным. Поэтому попытки запустить данный процесс предпринимались задолго до основной даты - 1 июля 1997 г. Что же касается системы образования, то интеграционные механизмы разрабатывались и применялись на практике начиная с конца 1970-х - начала 1980-х гг. Пионерами в этом начинании считаются три университета - университет Сунь Ятсена (中山 大学), Цзинаньский университет (暨南大学) и университет Хуацяо (华侨大学) . Данные университеты разработали специальные программы вступительных испытаний для студентов из Гонконга и начали прием абитуриентов с 1979 г. [Te, Postiglione 2018: 53]. Основной механизм, который позволял гонконгским выпускникам поступать в вузы материкового Китая, начал использоваться с 1981 г. и получил название «Единые вступительные экзамены для студентов из Гонконга, Макао, Тайваня, зарубежных районов и стран проживания китайских резидентов в университеты КНР» (Joint Entrance Examinations for Students from Hong Kong, Macao, Taiwan and Overseas Chinese-Resident Areas and Countries for Universities in PRC).

В середине 1990-х гг. началась системная работа по интеграции вузовских программ. Государственный комитет по образованию Китая рекомендовал университетам и колледжам гарантировать гонконгским студентам соответствующее качество подготовки. Восемь министерств страны в мае 1996 г. выпустили циркуляр, согласно которому определялись условия получения образования, транспорта и места жительства в континентальных районах Китая для студентов из Тайваня, Гонконга и Макао. Данный циркуляр был разработан Государственным комитетом по образованию, Министерством общественной безопасности, Министерством путей сообщения, Управлением гражданской авиации КНР и др. ведомствами, которые в той или иной степени касались вопросов реализации образовательных программ и социальных условий для студентов [Цзяоянь Цзу 1998: 141]. Согласно этим правилам, было запрещено любое повышение затрат со стороны студентов из перечисленных регионов.

Народный университет (中国人民大学) КНР в 1996 г. учредил 30 стипендий для студентов Гонконгского университета для обучения в летней школе китайского языка, а специалисты университета составили практический курс официального китайского языка для студентов Гонконга и Макао [Цзяоянь Цзу 1998: 141].

Несмотря на то что методика обучения и направления подготовки в вузах континентального Китая и Гонконга отличаются, все же следует отметить наличие спроса со стороны гонконгцев на получение образования в вузах КНР. Одним из наиболее популярных вузов являлся университет Цинхуа (清华大学), имеющий хорошую репутацию с точки зрения кадрового состава и качества подготовки. Еще одним фактором, определяющим спрос, являлось разнообразие направлений подготовки и образовательных программ в вузах континентального Китая. Третьим фактором были низкие затраты на обучение. Китайские исследователи выделяют такие факторы, как репутация страны и ее институтов, надежность и безопасность [Hu, Wotipka, Wen 2016: 155]. Другие рассматривают в качестве основания для выбора материкового Китая как места получения образования такие факторы, как вера в развитие Китая, блестящие перспективы, которые сулит знание китайского языка, и государственные стипендии [Jiani 2017: 571].

Практическая заинтересованность гонконгцев в получении образования в вузах КНР обусловлена необходимостью ведения бизнеса в разных регионах континентального Китая, что требует знания нормативно-правовой базы, раз- 
личных экономических и юридических аспектов торгово-экономической деятельности.

В свою очередь, в связи с вхождением в КНР гонконгское правительство стало шире использовать китайский язык. В качестве примера можно указать кампанию «учи китайский язык, чтобы выполнять свою работу». В бюджете на 1996-1997 гг. гонконгское правительство заложило 100 млн гонконгских долл. на приобретение программ по изучению китайского языка для своих чиновников [Цзяоянь Цзу 1998: 142]. Все это формирует спрос на преподавателей китайского языка для граждан Гонконга. Подготовка по данному направлению ведется в Пекинском педагогическом университете (北京师范大学).

\section{Современные механизмы интеграции}

В современных условиях сфера образования становится одним из направлений международного сотрудничества и средств публичной политики. КНР активно развивает сотрудничество с вузами мира, предлагает различные программы стажировок для студентов и школьников в Китае. Особое значение придается программе по распространению китайского языка и культуры через сеть институтов Конфуция по всему миру. Одной из форм международного образовательного сотрудничества является реализация совместных образовательных программ (СОП). Эта форма широко распространена как в Европе, так и в Азиатско-Тихоокеанском регионе. На сайте информационной платформы Министерства образования КНР приведены данные по реализации совместных образовательных программ по направлениям подготовки бакалавриата и магистратуры, которые реализуются совместно с зарубежными вузами и вузами Тайваня и Гонконга. По состоянию на 2020 г. СОП реализовывали 100 вузов КНР, партнерами из Гонконга были 5 университетов, Тайвань представлен двумя высшими учебными заведениями ${ }^{1}$.

В целях интенсификации сотрудничества в области образования, науки и технологий, оптимизации механизма академической мобильности студентов, подготовки высококвалифицированных кадров для конкретного региона, а также содействия эффективному сотрудничеству в политической, торговоэкономической, научно-технической и культурной областях страны создают сетевые университеты. Сетевой университет предполагает объединение университетов в одну сеть для подготовки специалистов по определенным областям.

Еще одной формой являются совместные образовательные учреждения. Практика создания совместных образовательных учреждений в КНР достаточно распространена, причем это касается не только высших учебных заведений. В 2019 г. в стране было 35 совместных учебных заведений, в т.ч. 7 детских садов, 1 основная средняя школа, 14 старших средних школ, 1 среднее профессиональное училище, 12 колледжей и университетов, реализующих программы высшего образования ${ }^{2}$.

В настоящее время сетевыми университетами с участием Гонконга и Китая являются Китайский университет Гонконга в г. Шэньчжэнь [ 香港中文大学

\footnotetext{
1 Официальное письмо Министерства образования КНР «О начале реализации в 2020 г. совместных образовательных программ между вузами КНР и зарубежных стран». Доступ: http://www.cdgdc.edu.cn/hzbx/pubDownload/hzbxgs/2gjsgztz.pdf (проверено 11.04.2021).

2 Развитие образования в 2019 г. - Официальный сайт Министерства образования КНР. Доступ: http://www.moe.gov.cn/jyb_sjzl/s5990/202008/t20200831_483697.html (проверено 07.04.2021).
} 
( 深圳)]; Шэньчжэньский университет; Китайский университет Гонконга (Гонконг), которые созданы по одной модели 1 .

\section{Университетские альянсы как особая форма интеграции}

Интеграция системы высшего образования КНР и Сянгана активно реализуется через университетские альянсы. Примечательно, что активность в этом вопросе проявляют обе стороны. Рассмотрим несколько примеров реализации таких альянсов.

Shanghai-Hong Kong University Alliance (SHUA) был основан в ноябре 2018 г. 16 университетами Шанхая и Гонконга. Цель $S H U A$ - установление более тесной связи между университетами-членами и содействие научно-исследовательскому сотрудничеству. Стоит отметить, что Китайский университет Гонконга $(C U H K)$ уже продолжительное время реализует сотрудничество с шанхайскими вузами в области научных исследований и академического обмена ${ }^{2}$.

Beijing-Hong Kong University Alliance (BHUA) был основан в апреле 2018 г. Китайским университетом Гонконга. Деятельность альянса направлена на сотрудничество университетов Пекина и Гонконга. В BHUA входят 20 университетов -8 гонконгских и 12 пекинских. Сотрудничество в основном реализуется в области совместных научно-исследовательских проектов и программ студенческих обменов. Основная задача альянса - повысить качество высшего образования ${ }^{3}$.

University Alliance of The Silk Road (UASR) был создан в мае 2015 г. Университетский альянс Шелкового пути включает в себя свыше 100 учреждений и НПО из более чем 22 стран и регионов. UASR способствует развитию партнерства вузов стран маршрута Шелкового пути в области научных исследований, культуры и политических исследований. Со стороны специального административного района в нем принимают участие Гонконгский городской университет, Гонконгский политехнический университет, Гонконгский баптистский университет, Гонконгский университет и Китайский университет Гонконга 4 .

The Association of University Presidents of China (AUPC) была основана в ноябре 1997 г. Ассоциация была инициирована президентами группы университетов Китая и одобрена Государственной комиссией по образованию (ныне - Министерство образования). В число 10 членов-основателей входят университет Гонконга, Китайский университет Гонконга, Гонконгский научно-технологический университет. В настоящее время в составе $A U P C 12$ университетов 5 .

Alliance of Asian Liberal Arts Universities основан в ноябре 2017 г. и объединяет гуманитарные вузы Азии. В Альянс азиатских гуманитарных университетов входит Гонконгский университет Линнань. Члены организации объединяют

1 中外合作办学. 硕士及以上中外合作办学机构与项目 (含内地与港台地区合作办学机构与项 目)名单 [Список китайско-зарубежных совместных учебных заведений и проектов со степенью магистра или выше]. Доступ: http://www.crs.jsj.edu.cn/aproval/orglists/1 (проверено 11.04.2021).

2 Office of Academic Links (China). Shanghai-Hong Kong University Alliance. Доступ: https:// www.oalc.cuhk.edu.hk/en/project/alliances/shua/ (проверено 11.04.2021).

3 Office of Academic Links (China). Beijing-Hong Kong University Alliance. Доступ: https:// www.oalc.cuhk.edu.hk/en/project/alliances/bhua/ (проверено 11.04.2021).

4 University Alliance of the Silk Road. Доступ: http://uasr.xjtu.edu.cn/About_UASR/ Introduction.htm (проверено 11.04.2021).

5 Office of Academic Links (China). The Association of University Presidents of China (AUPC). Доступ: https://www.oalc.cuhk.edu.hk/en/project/alliances/network2/\#: :text=The\%20 Association $\% 20$ of $\% 20$ University $\% 20$ Presidents $\% 20$ of $\% 20$ China $\% 20$ (AUPC) $\% 20$ was $\% 20$ founded,known\%20as\%20Ministry\%20of\%20Education) (проверено 11.04.2021). 
усилия для повышения качества гуманитарного образования и обмениваются опытом в научных исследованиях и преподавании ${ }^{1}$.

\section{Заключение}

Система образования в современных условиях является стратегически важным направлением внутренней и внешней политики государства. В КНР партия и правительство уделяют особое внимание развитию образования. Сфера образования является важным направлением не только с точки зрения подготовки национальных кадров для экономики, формирования гражданственности и патриотизма молодежи, но и как элемент «мягкой силы» государства на международной арене. Китайские стипендиальные программы, очень популярные среди студентов всего мира, были переформатированы в условиях пандемии и переведены в дистанционный формат. Система высшего образования Китая отреагировала сравнительно оперативно. К 02.02.2020 на 22 платформах были запущены около 24 тыс. вузовских онлайн-курсов, в т.ч. 1291 национальный учебный курс и 401 экспериментальный курс с использованием информационных технологий ${ }^{2}$. Наряду с системой массовых открытых онлайнкурсов университеты используют онлайн-трансляции, предоставляют видеозаписи лекций, проводят онлайн-семинары. Основные платформы, на базе которых происходит образовательный процесс, - Tencent Meetingapp, ZOOM, Rain Classroom $^{3}$. Примечателен опыт Гонконга, который еще в 2003 г. оказался эпицентром эпидемии атипичного тяжелого острого респираторного синдрома $(S A R S)$. В этих условиях вузам пришлось проводить занятия онлайн. В 2019 г. уже из-за волны протестов вузам автономии пришлось завершать учебный семестр в онлайн-формате. Вузы материкового Китая создали три рабочих органа (комитета) по поддержке онлайн-обучения: консультативный комитет по онлайн-обучению, комитет по обеспечению качества обучения в режиме онлайн, комитет по вопросам технической поддержки онлайн-обучения.

Таким образом, можно выделить несколько основных характерных черт, присущих процессу интеграции вузов КНР и САР Гонконг (Сянган). Во-первых, процесс интеграции вузовской системы был начат еще задолго до перехода Гонконга под юрисдикцию Китая. Во-вторых, можно отметить тенденцию к повышению интереса молодежи Гонконга к получению образования в «большом Китае», который обусловлен экономическими мотивами (относительно низкая стоимость обучения, возможность трудоустройства в государственных корпорациях или частных компаниях). В-третьих, государство в лице правительства КНР создает условия для интеграции вузов материкового Китая и Гонконга в форме университетских альянсов, которые направлены на объединение потенциалов для повышения качества высшего образования. Руководство страны понимает, что необходима системная работа с молодежью, особенно это стало актуальным после волны студенческих протестов в Гонконге в 2014 и 2019 гг.

В качестве основных барьеров на пути к интеграции можно выделить разницу в образовательной модели, которая присуща вузам КНР и Гонконга. В материковых вузах своя философия, основанная на традициях и ценностях

1 Alliance of Asian Liberal Arts Universities. Доступ: https://www.aalau.org/ (проверено 11.04.2021).

2 How does the Chinese education system cope with the virus outbreak challenge? Доступ: https://america.cgtn.com/2020/02/19/how-does-the-chinese-education-system-cope-with-thevirus-outbreak-challenge (проверено 11.04.2021).

3 Xiaoxiao Wang. Chinese Higher Education in Response to COVID-19. URL: https://iite. unesco.org/wp-content/uploads/2020/03/Tsinghua-University.pdf (accessed 11.04.2021). 
конфуцианства и других учений Китая. Гонконгские университеты базируются на западной философской мысли, истоки которой берут начало в Британии. Кроме того, до сих пор идет процесс формирования единой китайской нации, и этот процесс протекает не всегда гармонично. Подводя общий итог, можно сказать, что центральное правительство продолжит свою образовательную политику, несмотря на различные препятствия. Вопрос в том, насколько интенсивно будет протекать этот процесс и будет ли руководство страны форсировать процесс интеграции.

\footnotetext{
Работа выполнена в рамках государственного задания Министерства науки и высшего образования РФ, проект «Памятники письменности народов России и Внутренней Азии на восточных языках и архивные документы XVIII - нач. XXI вв. в контексте межцивилизационного взаимодействия», № 121031000302-9.
}

\section{Список литературы}

Гурулева Т.Л. 2020. Результаты выполнения программы реформы образования в Китае и задачи развития образования до 2022 года. - Китайское государство на заключительном этапе построения «среднезажиточного общества». Материалы ежегодной научной конференции Центра политических исследований и прогнозов. М.: ИДВ РАН. С. 81-92.

Цзяоянь Цзу. 1998. Вузы Гонконга и континентальных районов Китая обмениваются рукопожатиями (пер. Л.Г. Можаевой). - Социальные и гуманитарные науки. Отечественная и зарубежнная литература. Сер. 8. Науковедение. Реферативный журнал. № 3. С. 140-143.

Hu C., Wotipka C.M., Wen W. 2016. International Students in Chinese Higher Education: Choices, Expectations, and Experiences by Region of Origin. - Global Perspectives and Local Challenges Surrounding International Student Mobility (ed. by K. Bista, C. Foster). P. 153-177.

Jiani M.A. 2017. Why and How International Students Choose Mainland China as a Higher Education Study Abroad Destination. - Higher Education. Vol. 74. No. 4. P. 563-579.

Te A.Y.C., Postiglione G.A. 2018. Hong Kong Students Entering Mainland China Universities: a review of the admission scheme. - Public Administration and Policy. Vol. 21. No. 1. P. 50-67.

\section{THE PROCESS OF INTEGRATION OF UNIVERSITIES IN HONG KONG AND CHINA IN MODERN CONDITIONS}

\footnotetext{
Abstract. The article is devoted to the analysis of the main characteristic features of the process of integration of universities in Hong Kong and PRC in the modern period. Conventionally, two main stages of integration can be distinguished: starting from the end of the 1980s until 1997 and after the return of Hong Kong to the PRC jurisdiction. The authors determine the
} 
main mechanisms for the integration of universities and the motives for the admission of Hong Kong applicants to universities in Mainland China. Despite the ambiguous attitude of Hong Kong residents to the policies of the central government, the process of integration in education is bilateral.

Keywords: PR China, Hong Kong, higher education, integration, educational policy

АРШИН Константин Валерьевич - ученый секретарь Федерального исследовательского центра картофеля им. А.Г. Лорха (140051, Россия, Московская обл., г. Люберцы, пос. Красково, ул. Лорха, 23B; Kosta-10@yandex.ru)

\title{
ПОЛИТИКА УПРАВЛЕНИЯ МИГРАЦИЕЙ В КНР
}

\begin{abstract}
Аннотация. В течение последних нескольких десятилетий Китай демонстрирует значительный экономический рост. Многие эксперты справедливо связывают его с либерализацией китайской экономики, а также политикой открытых дверей, которая обеспечивает КНР инвестициями. Однако вне поля внимания оказывается миграционная политика, также внесшая существенный вклад в развитие страны. В статье предпринята попытка комплексного рассмотрения эволюции китайской миграционной системы с момента образования КНР в 1949 г. В рамках проведенного анализа автор отмечает как сильные стороны миграционной политики Китая, так и ее недостатки, препятствующие увеличению миграционного потока.
\end{abstract}

Ключевые слова: миграция, Китай, визы, трудовые мигранты, беженцы, дифференциация

B настоящее время Китай, будучи одной из наиболее стремительно развивающихся стран мира, характеризуется развертыванием крайне динамичных миграционных процессов. О масштабах этих процессов можно судить, например, по объемам миграционного обмена Китая с другими странами. В частности, в 2015 г. «численность китайских мигрантов, выехавших из Китая в другие страны, составила более 273 млн чел., а число иностранцев, прибывших в Китай - 76,31 млн чел.» [Сюнь Ю 2018: 132]. Очевидно, что подобные миграционные потоки оказывают существенное влияние на экономическое и социально-политическое развитие как Азиатского региона, так и всего мира.

Однако необходимо отметить, что указанная ситуация характерна исключительно для Китая XXI в. В течение длительного периода страна проводила политику закрытых дверей, всячески ограничивая миграцию и, более того, препятствуя нахождению на своей территории иностранцев. Впервые ограничения на пребывание иностранцев в стране были введены в 1951 г. Временными действующими правилами контроля за въездом в страну и выездом из страны, также проживанием в стране иностранцев-резидентов. Эти правила ограничивали для иностранцев получение разрешения на посещение Китая, а в случае, если такое разрешение было предоставлено, устанавливали правила контроля за подобными иностранцами. Впоследствии вплоть до 1977 г. указанные правила периодически переутверждались в разных нормативных правовых актах. Так, в 1954 г. были приняты Временные меры по управлению въездом в страну и выездом из страны иностранцев-резидентов, в том же году утверждены Временные правила выдачи виз и регистрации прибывающих иностранцев и Временные правила путешествия иностранцев. В 1964 г. приняты Правила управления въездом в страну и выездом из страны, транзитом, пребыванием и путешествием иностранцев. 